\title{
IDENTITAS DAYAK DAN MELAYU DI KALIMANTAN BARAT
}

\author{
IDENTITY OF DAYAK AND MELAYU \\ IN WEST KALIMANTAN
}

\author{
Yusriadi \\ Pusat Studi Bahasa dan Masyarakat Borneo (PSBMB) IAIN Pontianak \\ Jln. Letjen Suprapto No. 19 Pontianak \\ yusriadi@yahoo.com
}

Diterima tanggal 29 Agustus 2017

Disetujui tanggal 9 Mei 2018

\begin{abstract}
Competition and conflict, as well as the harmony and fraternity between Dayaks and Malays colored the public spaces in West Kalimantan. The two main groups (the majority) in West Kalimantan underwent tidal and low tide. It is always interesting to observe, especially in the context of identity. I wants to see how the identity is related to the DayakMalay bipolarity issue. The data were obtained from various sources of documentation and books, indicating that behind the identity divergences between Dayak and Malays, there is an element of equality. Both, live in the same room and some source or origin. The next process shows the acceptance and use of cultural identity to be the material for constructing a group identity building. In the beginning, Dayak identity was used in a forced way, while Malay identity was initially accepted openly. Over time, both identities were used by and for two different groups. Each reinforces (maintains) identity with certain changes to existing cultural elements. The identity of Dayak and Malay culture remains fluid but the movement of change tends to opposite direction, and widens the distance between those two. It is precisely affecting of sustained rivalry, so this can become major isues.
\end{abstract}

Keywords: identity, cuture identity, ethnic identity, Dayak culture, and Malay culture.

\begin{abstract}
Abstrak
Persaingan dan konflik, serta kerukunan dan persaudaraan antara Dayak dan Melayu mewarnai ruang publik di Kalimantan Barat. Kedua kelompok utama (mayoritas) di Kalimantan Barat menjalani hubungan pasang dan surut. Keadaan inilah yang selalu menarik diamati, khususnya dalam konteks identitas. Penulis ingin melihat bagaimana identitas berkelindan di balik isu bipolaritas Dayak-Melayu. Tulisan ini merupakan hasil pemikiran yang diperkuat dengan data pendukung. Data tersebut diperoleh dari berbagai sumber
\end{abstract}


Handep, Vol. 1, No. 2, Juni $2018: 1-16$

dokumentasi dan terbitan, yang di antaranya menunjukkan bahwa di balik perbedaan identitas antara Dayak dan Melayu dapat ditemukan pula persamaan pada beberapa unsur. Kedua identitas itu tumbuh di ruang yang sama dan sebagian darinya berasal dari sumber atau asal-usul yang sama. Proses selanjutnya memperlihatkan penerimaan dan penggunaan identitas budaya menjadi bahan untuk pengonstruksian bangunan identitas kelompok. Pada mulanya, identitas Dayak digunakan secara terpaksa, sedangkan identitas Melayu diterima dengan terbuka. Seiring perjalanan waktu, kedua identitas itu dipakai oleh dan untuk dua kelompok yang berbeda. Masing-masing memperkuat identitas dengan perubahan-perubahan tertentu pada unsur-unsur budaya yang sudah ada. Identitas budaya Dayak dan Melayu tetap cair tetapi gerakan perubahan itu cenderung ke arah yang berlawanan dan memperlebar jarak di antara keduanya. Itu pulalah yang menyebabkan rivalitas berkelanjutan, sehingga persoalan yang kecil dapat menjadi besar.

Kata kunci: identitas, identitas budaya, identitas etnik, budaya Dayak, dan budaya Melayu.

\section{A. PENDAhULUAN}

Tema tentang identitas dan budaya lokal selalu menarik perhatian masyarakat Kalimantan Barat. Barubaru ini, publik daerah ini dibuat terpesona oleh silang pendapat soal Rancangan Peraturan Daerah tentang Masyarakat Adat yang telah dibahas oleh anggota Dewan Perwakilan Daerah Provinsi Kalimantan Barat. Prokontra mengenai Raperda ini ditarik dalam wilayah 'identitas etnik' dan menyebabkan tarik menarik yang luar biasa. Kedua belah pihak terperangkap pada dua kutub: Dayak dan bukan Dayak (Suara Pimred, 2016:1). Dayak diberi makna sebagai pihak yang mendukung dan bukan Dayak diberi makna sebagai pihak yang menolak.

Diskursus mengenai identitas dan etnisitas memang sering muncul di ruang publik di daerah ini karena atau menyusul ketegangan-ketegangan yang terjadi antar-kelompok etnis. Rivalitas etnis selalu muncul dalam momentummomentum tertentu, seperti pemilihan umum dan pemilihan kepala daerah (Djajadi, 2016: 1-6). Konflik atas nama etnik sudah sering kali terjadi dengan melibatkan kelompok-kelompok masyarakat. Karena itu, seorang sosiolog Kalimantan Barat mengatakan bahwa jika situasi tidak berubah dan kondisi-kondisi tertentu sebagai prasyarat terjadinya konflik terpenuhi, maka konflik akan terus terulang dalam siklus 30 tahunan (Alqadrie, 2012: 203 204).

Tulisan ini dimaksudkan untuk memperkaya diskursus mengenai pembentukan dan pemaknaan identitas etnis dan budaya. Kita akan membicarakan bagaimana konstruksi identitas tersebut disusun sehingga dapat menjadi pemersatu kelompok, atau sebaliknya dapat pula menjauhkan satu kelompok dari kelompok yang lain.

Data yang digunakan dalam tulisan yang berupa hasil pemikiran ini diperoleh dari bahan pustaka. Bahanbahan tersebut diperoleh dari tulisan yang merupakan hasil penelitian dan 
catatan perjalanan, serta berita di media massa, baik cetak maupun elektronik.

Identitas atau jati diri sering kali menjadi bahan pembicaraan yang hangat. Diskursus tersebut tersuguh di ruang publik hampir di setiap kesempatan, terutama ketika muncul pemberitaan-pemberitaan atau isu-isu ketegangan antarkelompok.

Secara awam, jati diri merupakan nama lain dari identitas atau ciri. Dari aspek leksikal, konsep jati diri itu dapat dipahami melalui Kamus Besar Bahasa Indonesia (KBBI), yakni: 1) ciri-ciri, gambaran, atau keadaan khusus seseorang atau suatu benda; identitas; 2) inti, jiwa, semangat, dan daya gerak dari dalam; spiritualitas (https://kbbi. kemdikbud.go.id) diakses pada Agustus 2017).

Dalam dunia akademik, istilah identitas atau identity lebih sering dipakai dibandingkan jati diri. Identity adalah kata dari bahasa Inggris yang berasal dari bahasa Latin identidem atau idem yang berarti persamaan atau kesinambungan (Shamsul, 2001: 1314). Mesthrie dan Tabouret-Keller (2001: 165-168) menyebutkan bahwa identitas adalah sifat-sifat (ciri-ciri dan sebagainya) yang terdapat pada seseorang atau sesuatu yang sebagai suatu keseluruhan memperkenalkannya atau mengasingkannya daripada yang lain.

Setidaknya ada dua pendapat yang muncul berkaitan dengan identitas itu. Pertama, identitas sebagai satu ciri yang stabil (beku) yang tidak berubah. Kalau sekelompok orang dikenal dengan identitas itu, maka selamanya identitas itu harus melekat pada dia. Tidak bisa dibuang, tidak bisa diganti. Kedua, identitas sebagai ciri yang cair (fluid) yang dapat berubah sesuai kepentingan. Identitas seseorang bisa dipilih menurut kepentingan dan kemauan. Dari dua pendapat itu, pendapat kedua yang menganggap identitas sebagai sesuatu yang cair lebih sering dipakai di kalangan ilmuan (Shamsul, 1996:476499).

Sekarang ini semua orang yang melakukan kajian identitas menyepakati bahwa identitas itu dianggap sebagai sesuatu yang cair, yang dapat dibentuk, dipertahankan, dan dapat diubah. Pertimbangannya terletak pada kebutuhan yang sifatnya pragmatis (Shamsul, 2001: 13); Mesthrie dan Tabouret-Keller, 2001: 167; Yusriadi, 2005: 41-60).

Sementara itu dari sisi pembentukan dan pilihannya, identitas bisa dibentuk dan dipilih oleh si pemilik atau pemakai. Sifatnya bisa berasal dari dalam (self define), namun bisa juga dari luar (authority define) yang dibentuk dan dipakai oleh (dari) orang lain ${ }^{1}$. Kedua bentuk identitas ini bisa diterima, bisa juga ditolak, dan bisa juga

\footnotetext{
${ }^{1}$ Dalam masyarakat di Kalimantan Barat, identitas yang dibentuk oleh orang luar bisa dilihat dalam contoh sebagai berikut. Seseorang yang bernama Udin karena sifatnya yang nakal dan degil lalu dipanggil Udin Kera'. Ahmad, karena bentuk badannya yang tinggi jangkung, dipanggil Amat Jangkung.
} 
Handep, Vol. 1, No. 2, Juni 2018 : 1-16

pada mulanya ditolak lalu kemudian diterima.

Bahan yang digunakan dalam membentuk identitas bisa bermacammacam. Ada yang mengaitkan identitas dengan kondisi sosial, geografis, etnik, gender dan kebangsaan (Abdurrahman, 2009: i-ix; Shamsul, 2001: 13-34). Misalnya, ada identitas yang dipakai berkaitan dengan kelas sosial yang memunculkan identitas kelas elite dan kelas biasa; berkaitan dengan agama yang dianut, lalu muncullah identitas sebagai Muslim-Kafir, Kristiani, Khonghucu, Yahudi; ada yang dipakai berkaitan asal geografi, lalu muncullah orang Sambas, orang Pontianak, orang Ulu, orang Laut, orang Darat; dan ada yang dipakai berkaitan dengan kebangsaan/nasionalisme, muncullah Indonesia, Malaysia, Amerika.

Sedangkan dari sisi jumlah, identitas itu biasanya tidak tunggal atau satu. Identitas itu banyak dan tersusun dalam set pengetahuan (stock of knowledge), bisa dipilih sesuai dengan konteks yang diinginkan². Misalnya, seorang bernama Fulan, dia bisa mempunyai identitasnya sebagai orang Islam, terkadang orang Melayu, terkadang orang Dayak Islam, terkadang seorang Mualaf, terkadang orang Indonesia, terkadang orang Pontianak, terkadang orang Ulu,

\footnotetext{
2 Tentang hal ini, bisa dilihat dalam Yusriadi (2009:1-3). Dalam tulisan ini ditunjukkan contoh seseorang dapat mengaku dirinya sebagai orang Pontianak, orang Islam, orang Melayu, orang lelaki, dan lain-lain. Setiap orang memiliki banyak identitas (multiple identity).
}

terkadang pegawai negeri (PNS), terkadang orang Departemen Agama (Depag), dan lain-lain.

Kajian mengenai identitas budaya secara umum sudah banyak dilakukan. Para ilmuan mengkaji dari berbagai sisi. Misalnya, dari sisi identitas bahasa, identitas pakaian, identitas makanan, identitas fisik, identitas adat, dan lain sebagainya (Yusriadi, 2005: 1-45). Sementara itu, kajian mengenai identitas masyarakat dan budaya di Kalimantan Barat, khususnya tentang Dayak dan Melayu di Kalimantan Barat, akan ditampilkan dalam pembahasan di bawah ini.

\section{B. HASIL DAN BAHASAN \\ 1. Identitas Dayak dan Budaya Dayak}

Dayak merupakan kelompok masyarakat yang besar di Kalimantan Barat. Besar dari sisi jumlah, persebaran dan peranannya. Dari sisi jumlah, walaupun tidak ada angka resmi, bilangan komunitas ini mencapai 30-40 persen dari total penduduk Kalbar ${ }^{3}$, dan memiliki 151 subsuku dan 100 subsubsuku (Yusriadi, 2008:23-30). Sedangkan dari sisi persebaran, Dayak tersebar di semua wilayah kabupaten, di pesisir dan pedalaman. Konsentrasi terbesar ada di kabupaten Landak,

\footnotetext{
${ }^{3}$ Badan Pusat Statistik (BPS) pada tahun 2000 pernah melakukan sensus penduduk yang mencakup bilangan penduduk berdasarkan etnik. Namun ketika hasil statistik ini dipublikasikan terjadi masalah besar, sehingga kemudian publikasi itu ditarik kembali dan data itu dianggap tidak pernah ada.
} 
Sanggau, dan Bengkayang. Dari sisi peran, terutama peran politik, tokohtokoh Dayak memainkan peranan penting. Selain sebagai gubernur, beberapa di antaranya menjadi kepala daerah di kabupaten, baik sebagai bupati atau wakil bupati. Ada pula yang menduduki jabatan sebagai kepala dinas, serta ketua dan anggota DPRD di provinsi dan kabupaten. Mereka adalah sebagai pengambil kebijakan di wilayah kerjanya masing-masing.

Istilah Dayak digunakan pertama kali oleh Rademaker tahun 1790 untuk menyebut komunitas yang sekarang kita kenal sebagai pribumi yang beragama bukan Islam. Istilah ini sejajar dengan penggunaan istilah Melayu untuk penduduk yang beragama Islam (Alloy, et al., 2008: 9).

Istilah Dayak ini pada mulanya tidak diterima oleh orang pribumi yang bersangkutan. Mereka tahu orang lain menggunakan istilah itu untuk mereka dengan konotasi yang negatif $f^{4}$. Apalagi kemudian seiring dengan konsep Dayak itu tersirat pula makna kafir. Van Hulten (1992: 133) menceritakan pengalamannya ketika bernegosiasi dengan orang Dayak di sebuah kampung. Orang kampung itu mengizinkan pastor masuk dengan syarat tidak menyinggung orang

4 Aloy, et al. (2008:10) menulis: "Dulunya, mereka tidak mengenal istilah Daya', Dyak, Daya atau Dayak untuk menyebut identitas mereka. Bahkan, mereka sadar bahwa penyebutan Dayak dari pihak luar yang ditujukan kepada mereka itu memiliki makna jorok, kotor, terbelakang, bodoh dan sebagainya." kampung sebagai orang kafir. Dahulu bagi pribumi bukan Islam, identitas Dayak dianggap sebagai sesuatu yang menghina dan memalukan. Mereka menganggap istilah itu digunakan orang untuk menyebut mereka dalam konotasi negatif 5 .

Meskipun menolak menggunakan identitas Dayak, tetapi kalangan tertentu dari orang yang disebut Dayak itu melihat ada satu ikatan emosional yang bisa dipakai untuk menyatukan kekuatan politik pribumi bukan Islam. Hal ini menarik untuk dicermati dan dijelaskan lebih mendalam. Apalagi di masa itu pihak yang memiliki otoritas (pemerintah) "memaksakan" penggunaan istilah Dayak untuk semua kebijakan mereka, misalnya dalam pengelompokan sosial, istilah Dayak ini selalu dipakai (Veth, 1854: 4; 136; Enthoven, 1903:100; 123; 143). Kondisi seperti ini membuat orang pribumi mau tidak mau dan perlahan tapi pasti harus menerimanya. Penggunaan yang meluas membuat mereka tidak memiliki pilihan lain.

Beberapa sumber menyebutkan pada masa awal penerimaan penggunaan identitas itu, kalangan

\footnotetext{
${ }^{5}$ Colongon, Jr. menulis: "Kata Dayak dulunya dipakai untuk sebutan yang menghina. Sekarang Dayak merupakan identitas budaya, sosial dan etnisitas masyarakat adat di Pulau Borneo (2013:xxxix).

${ }^{6}$ Ketika mendeskripsikan tentang masyarakat di pedalaman Veth yang mengutip Tobias, Hartmann, Francis, dan v. Lijnden mengelompokkannya pada tiga kelompok, yaitu Maleijers (Melayu), Chinezen (Cina), Dajaks (Dayak 854:13).
} 
Handep, Vol. 1, No. 2, Juni 2018 : 1-16

pribumi menerima dengan setengah hati, kalau bukan terpaksa. Mereka bisa menerima identitas Dayak tetapi dalam bentuk Daja atau Daya. Daja atau daya dianggap lebih cocok untuk menggambarkan kekuatan bangkit dan menggambarkan semangat (Alloy, et al., 2008: 9; Pasti, 2003:105-142). Pemaknaan yang diterima dan dipakai oleh mereka (self identification) berbeda dibandingkan dengan pemaknaan yang diguna dan pakai oleh orang luar.

Pada masa awal kemerdekaan Indonesia, sekitar tahun 1946, istilah Daja atau Daya digunakan oleh Oevang Oeray dan kawan-kawan ${ }^{7}$ untuk menyatukan kekuatan politik dengan melahirkan Daja in Action (DIA), yang kemudian berubah menjadi Partai Persatuan Daya (PPD) di tahun 1945. PPD yang mendapat 12 kursi di Kalimantan Barat pada Pemilihan Umum 1955 mengantarkan Oevang Oeray menjadi gubernur di tahun 1960. Beberapa tahun kemudian kekuatan politis PPD meredup dan penggunaan istilah Daya jarang digunakan lagi (Aju dan Zainuddin, 2013: 28-30). Pada fase ini, identitas Dayak cenderung dianggap sebagai sesuatu yang negatif (Lihat Yusriadi, 2008a:21)

Hingga kemudian, pada 1980-an, identitas Dayak mulai sering digunakan

\footnotetext{
${ }^{7}$ Aju dan Syafaruddin (2012:51) menyebutkan nama tokoh yang terlibat dalam gerakan ini, antara lain A.F. Korak, Pius Ungkang, A. Djelani, F.C. Palaoensoeka, M. Andjioe, Rafael Serang, Hieronimus Liwah, W.J. Pilang, F.H. Aboe, dan S.P. Boega.
}

oleh orang pribumi, terutama para aktivis, intelektual, dengan makna yang positif. Pada masa itu istilah Dayak menjadi pengikat untuk bangkit dari keadaan yang disebut terpinggirkan (marginal). Penggunaan makna ini diterima secara meluas, terlebih di masa itu jabatan politik memang bukan dipegang oleh orang Dayak. Padahal ada anggapan umum bahwa orang Dayak adalah penduduk asli Kalimantan Barat. Di sini identitas menjadi pengikat dari aspek budaya sehingga membentuk satu entitas baru dalam masyarakat Kalimantan Barat. Bahkan di tahun 1990-an, istilah Dayak di Kalimantan Barat mulai dipakai pula oleh kalangan pribumi yang memeluk agama Islam, yang sebelumnya lebih sering dikenal dengan identitas Melayu, Senganan, atau Laut. Sejak saat itu istilah Dayak Islam pun diperkenalkan (Yusriadi dan Haitami (ed.), 2001: 112; Yusriadi dan Fahmi (ed.), 2007: vxiii) ${ }^{8}$.

Apa yang terjadi pada orang Dayak ini tidak muncul dengan sendirinya. Ada 'agen' yang menjadi pendorong kuat dari kemunculan ini. Kehadiran Ovang Oeray di tahun 1940-1950-an merupakan fase pertama dari pendorong $i^{9}$. Meskipun setelah era kepemimpin-

\footnotetext{
${ }^{8}$ Sebenarnya di tahun 1980-1990 orang-orang yang berasal dari Kalimantan Barat ketika berada di Pulau Jawa kerap kali diberi identitas Dayak oleh orang luar. Sebaliknya, ada pula orang Bugis Kalimantan Barat yang merantau ke Jawa mengaku dirinya sebagai orang Dayak Kalimantan.

9 Aju dan Zainuddin (2013:27-29) malah mencatat perkembangan sebelum era kepemimpinan Oevang Oeray, yakni di saat
} 
an Oevang Oeray istilah Dayak sebagai identitas etnik sempat hilang (meredup) dan kata Dayak itu sendiri tetap berkesan negatif, tetapi di tahun 1980an muncul agen pendorong baru yang melibatkan banyak pihak. Misalnya, Dewan Adat Dayak (DAD) Kabupaten Pontianak tahun 1985, Yayasan Karya Sosial Pancur Kasih tahun 1987, dan Institute Dayakologi Research and Development (IDRD) tahun 1990. Institusi-institusi ini merupakan jentera dari perubahan itu. IDRD sebagai lembaga advokasi (pemberdayaan) yang anggotanya terdiri dari kalangan intelektual telah mencatatkan diri sebagai lembaga yang paling berperan dalam revitalisasi kebuda-yaan Dayak di Kalimantan Barat ${ }^{10}$ (Wahono, et al., 2013: 18-25).

Meskipun pada mulanya identitas Dayak digunakan dalam konteks politik

terdapat beberapa intelektual Dayak terutama dari Kapuas Hulu yang belajar di sekolahsekolah Belanda di Pontianak. Mereka mendirikan perkumpulan orang Dayak dan kemudian menjadi pelopor gerakan kebangkitan. Tokoh di era ini antara lain Palaunsoeka dan Kapat.

${ }^{10}$ Momen penting kebangkitan Dayak di Kalimantan Barat ditandai dengan diselenggarakannya ekspo budaya Dayak 1998 di Pontianak. Pertemuan ini melibatkan para intelektual dan tokoh Dayak dari berbagai wilayah, beserta para pembicara yang berasal dari dalam dan luar negeri. Forum ini disebut sebagai pertemuan kedua terbesar setelah pertemuan Tumbang Anoi di Kalimantan Tengah tahun 1894. Salah satu hasil penting yang patut untuk dicatat adalah pembakuan penulisan Dayak dari yang sebelumnya ditulis Daya', Dyak atau Daya (Alloy, et al., 1998: 10). tetapi kemudian setidaknya di tahun 1990-an identitas ini memasuki ruang budaya yang lebih luas secara formal ${ }^{11}$.

Ketika di tahun 1999 muncul ketegangan antara orang Dayak dan Melayu berkaitan dengan pemilihan anggota MPR Utusan Daerah Kalbar, berdirilah organisasi Ikatan Keluarga Dayak Islam (IKDI). Organisasi ini didirikan oleh orang-orang Dayak yang beragama Islam dengan tokohnya, antara lain H. Alamsyah (akademisi) dan Rudy Alamsyahrum (politisi). Kehadiran organisasi ini menunjukkan penerimaan istilah Dayak secara formal dan lebih luas di daerah ini melewati batas yang selama ini telah dipakai, yaitu pribumi-bukan Islam. Sebelumnya, setiap orang pribumi yang memeluk Islam cenderung disebut Melayu. Orang yang masuk Islam disebut sebagai "masuk Melayu" (Yusriadi dan Fahmi (ed.), 2007: vi).

Alqadrie (2012:12) melihat hal ini sebagai kesadaran etnis (ethnic consciousness). Hal ini menurutnya merupakan konsekuensi dari bangkitnya kelompok etnik dari proses keterpinggiran (marginalized).

Kesadaran itu mendorong mereka menjadi kreatif untuk menjadikan pelbagai bahan budaya yang ditampilkan dan dipersembahkan sebagai identitas kelompok etnik.

11 Penting juga ditekankan di sini bahwa gerakan pemberdayaan dalam berbagai bidang, baik budaya, ekonomi maupun sosial, juga tetap berkelindan dengan bidang politik. Situasi ini tidak terpisahkan antara satu dengan yang lainnya. 
Handep, Vol. 1, No. 2, Juni 2018 : 1-16

Budaya itulah yang digali, dikembangkan dan dipromosikan kepada masyarakat luas. Hari ini, ketika membicarakan Dayak, dalam mindset (pikiran) banyak orang bukan hanya akan terbayang pada pribumi bukan Islam, melainkan juga pada budaya Gawai, Naik Dango, tato khas, tarian perang, musik etnik, serta bahasa tertentu $^{12}$, hukum adat, pakaian dari kulit kayu dan manik-manik, topi dari bulu burung, rumah panjang (betang, lamin), mungkin juga telinga yang panjang. Meskipun dalam beberapa keadaan, tidak semua bayangan itu tepat, tetapi dalam batas tertentu bisa diterima sebagai bagian dari identitas Dayak. Bayangan itu menjadi simbol bagi komunitas ini.

Kehadiran sanggar-sanggar budaya, Sekretariat Bersama Kesenian Dayak (Sekberkesda), serta penyelenggaraan acara Gawai Dayak di Kalimantan Barat secara berkala menjadi bagian dari upaya pemertahanan, atau mungkin lebih tepatnya pemupukan, identitas Dayak di daerah ini. Selain itu, belakangan ini semakin banyak organisasi atau

${ }_{12}$ Konsep "bahasa Dayak" tidak merujuk pada bentuk bahasa tertentu. Dalam masyarakat Dayak ada banyak bahasa yang digunakan, antara yang satu dengan yang lain berada dalam cabang bahasa yang berbeda. Misalnya, bahasa Ahe (Kanayatn) berbeda cabang bahasa dengan bahasa Bekatik dan Jangkang (Bidayuh). Bahasa ini juga berbeda dibandingkan bahasa Taman dan Kayan. Lebih jauh, deskripsi tentang pengelompokan bahasa di Kalimantan (bagian) Barat dapat merujuk pada Collins (1999: 1-16). kelompok yang menggunakan nama Dayak, di antaranya Bala Adat Dayak, Ikatan Pemuda Dayak, Bakor K2 MAD, dan Fopad. Kehadiran lembagalembaga ini menunjukkan bahwa identitas Dayak sudah diterima dan didukung secara meluas oleh banyak orang. Gerakan mereka sering kali politis, tetapi secara simbolik mereka menggunakan simbol-simbol budaya dalam aksinya.

\section{Identitas Melayu dan Budaya Melayu}

Seperti juga Dayak, Melayu adalah kelompok dominan di provinsi ini. Tidak diketahui pasti jumlah mereka tetapi perkiraan kasar berjumlah sekitar 40-50 persen dari keseluruhan jumlah penduduk Kalimantan Barat (Yusriadi, 2008a: 2-3; Purba, et al., 2011: 160)

Pembentukan identitas Melayu dalam konteks Kalimantan Barat dimulai sejak Islam masuk ke wilayah ini $^{13}$. Namun belum ditemukan hasil hasil kajian yang dapat menunjukkan kapan persisnya awal mula penggunaan istilah Melayu sebagai identitas etnik di Kalimantan Barat.

Seperti disinggung di atas, identitas ini digunakan sebagai bagian dari polarisasi penduduk pribumi di Kalimantan Barat (Yusriadi dan

13 Membicarakan Melayu di Kalimantan Barat tidak lepas dari konsep Melayu secara umum di Nusantara. Melayu, secara umum dipahami sebagai satu entitas kemasyarakatakan, yakni masyarakat lokal yang menganut agama Islam, beradat istiadat "Melayu", dan berbahasa Melayu (Shamsul, 2001: 4-5). 
Haitami, 2001:1-12, Yusriadi, 2008: 215). Melayu digunakan untuk menyebut identitas penduduk Kalimantan Barat yang beragama Islam. Hampir di semua kawasan di pusat kebudayaan Melayu (misalnya ibu kota kecamatan) mengenal konsep "menjadi Melayu" atau "masuk Melayu". Istilah ini merujuk kepada orang yang memeluk agama Islam (Purba, et al., 2011: 7-10; Yusriadi, 2002: 1-10).

Berbeda dengan Dayak, sejak awal identitas Melayu di Kalimantan Barat digunakan dalam konteks positif dan karena itu lebih mudah diterima dan dipakai oleh masyarakat secara meluas. Orang luar menyebut mereka Melayu dan mereka sendiri juga memakai sebutan itu. Bahkan, dalam konteks sosial-keagamaan di Kalimantan Barat, orang yang masuk Islam akan disebut sebagai orang Melayu. Istilah "masuk Melayu" yang dikenal di beberapa tempat di Kalimantan Barat merupakan penguatan atas gambaran tersebut. Identitas "masuk Melayu" bukan saja berlaku untuk orang pribumi yang bukan Islam yang kemudian memeluk agama Islam, melainkan juga dipakai oleh orang bukan pribumi yang bukan Islam yang kemudian memeluk agama Islam ${ }^{14}$.

${ }^{14}$ Gambaran tentang hal ini dapat dilihat dalam tulisan Yusriadi (2002: 1-13). Dalam tulisan tersebut diungkapkan tentang seorang lelaki Jawa beragama Kristen, setelah dia melakukan konversi ke agama Islam, dia dipanggil dengan nama "Melayu Baru". Penggunaan nama ini begitu meluas sehingga banyak orang tidak tahu siapa nama dia sebenarnya. Di tahun 1990-an
Melayu sebagai identitas politik dan budaya di Kalimantan Barat muncul dalam berbagai bentuk. Sebagai identitas politik, Melayu dikaitkan dengan kesultanan dan kekuasaan, khususnya kekuasaan masa lalu. Di Kalbar sendiri teridentifikasi setidaknya 13 kerajaan atau pertuanan Melayu, mulai dari Pontianak, Sambas, Mempawah, Ketapang, Sukadana, hingga Landak dan Sintang (Purba, et al., 2011:48-74). Kekuasaan masa lalu itu sering kali, kalau tidak selalu, menjadi pantulan untuk melihat situasi yang dihadapi saat ini. Oleh karena itulah Melayu sering dikaitkan dengan jabatan dan kekuasaan wilayah teritori pemerintahan ${ }^{15}$.

Pada aspek budaya, bentuk identitas budaya Melayu yang sifatnya umum merujuk kepada orang Melayu secara keseluruhan. Contohnya adalah budaya silat, jepin, barzanji, tepung tawar, dan juadah yang dianggap sebagai budaya Melayu yang umum. Sedangkan bentuk identitas budaya yang sifatnya khusus merujuk kepada sub-Melayu. Misalnya, identitas bubur paddas, kue lapis, saprahan, dan

pola ini mulai berubah. Orang pribumi (Dayak) yang memeluk agama Islam menggunakan identitas Dayak Islam (Yusriadi dan Haitami, 2001:1-12).

15 Tentang hal ini simak penjelasan panjang lebar dan kritis dalam Iqbal Djayadi (2016:1-10). Sedangkan paparan lebih lengkap mengenai Melayu dan politik bisa disimak dalam Mahathir Mohammad (1997:1-18, 39-137, 206-222) atau dalam Purba, et al., (2011:1-9). 
Handep, Vol. 1, No. 2, Juni 2018 : 1-16

balale' untuk masyarakat Melayu Sambas; masakan asam pedas dan meriam karbit untuk Melayu Pontianak dan sekitarnya; ale-ale untuk makanan khas Melayu Ketapang, temet (kerupuk basah) dan lamoy untuk masyarakat Melayu di Kapuas Hulu. Contoh lain dari identitas budaya Melayu yang bersifat khusus adalah batik pucuk rebung sebagai identitas Melayu Pontianak, syair gulung sebagai identitas Melayu Ketapang, tumpang negeri sebagai identitas Melayu Ngabang. Identitas budaya yang seperti ini umumnya masih terjaga keberlangsungannya hingga kini dan ditampilkan dalam berbagai kegiatan.

Selain dalam tradisi upacara adat, kesenian, dan kuliner, ada pula identitas lain yang dapat mem-perlihatkan identitas budaya Melayu yang bersifat khusus, yaitu dialek. Misalnya, dialek Sambas untuk orang Melayu Sambas (dan Singkawang), dialek Melayu Pontianak untuk orang Melayu Pontianak, dialek Melayu Ketapang untuk orang Melayu di Ketapang, dialek Sanggau untuk orang Melayu di Sanggau dan Sekadau, dialek Melayu Sintang untuk Melayu Sintang, dialek Melayu Pinoh untuk Melayu di penghuluan Sungai Melawi, Melayu Putussibau untuk orang Melayu di Putussibau dan Semitau, dialek Melayu Embau untuk orang Melayu di sepanjang Sungai Embau, dialek Melayu Selimbau, untuk orang Melayu di Selimbau, dan masih banyak lagi dialek lainnya. (Yusriadi, 2006: 137)
Identitas Melayu dari bahan budaya ini diperkuat dengan pembentukan lembaga Majelis Adat dan Budaya Melayu Kalimantan Barat (MABM) di Pontianak tahun 1997 dan pembangunan rumah Melayu Kalbar di Pontianak tahun 2003. MABM melakukan pengukuhan identitas Melayu antara lain melalui pergelaran Festival Seni Budaya Melayu (FSBM). Pada festival ini diselenggarakan pentas tari, tampilan pakaian adat, penge-nalan tradisi khusus (seperti saprahan yaitu makan bersama secara berkelompok dalam satu majelis), dan lain sebagainya. Selain itu, muncul juga organisasi-organisasi lain yang mengatasnamakan Melayu, sebagai contoh Melayu Arus Bawah, Laskar Melayu, Permak, Persatuan Forum Komunikasi Pemuda Melayu (PFKPM), Pemuda Melayu, dan Perkumpulan Orang Melayu (POM). Sekalipun lembaga-lembaga tersebut lebih banyak yang bergerak di bidang yang berkaitan dengan gerakan politis, tetapi mereka memilih simbol budaya Melayu sebagai titik perhatian utama. Maka, di Pontianak terlihatlah kegiatankegiatan pentas seni, saprahan massal, serta pawai atau kirab budaya Melayu.

\section{Penguatan Identitas dan Hubungan Antarkelompok}

Identitas merupakan pilihan pragmatis. Seseorang menggunakan identitas tertentu karena pilihannya dan selalu ada pertimbangan-pertimbangan khusus di balik pilihan itu. Konsep yang dikemukakan Shamsul (2001: 13-31) 
ini dapat membantu kita memahami apa yang sedang terjadi pada orang Dayak dan Melayu di Kalbar.

Dua komunitas yang tinggal di ruang geografis yang sama, bahkan sebagian di antaranya memiliki asalusul yang sama (Yusriadi, 2008: 1-16) sejak lama memperlihatkan semacam "rivalitas" atau ethnic rivalry dalam hal politik dan juga budaya. Dalam hal politik secara kasat mata pertarungan kandidat kepala daerah hampir selalu dilihat dalam dua kutub: DayakMelayu. Pada Pemilihan Gubernur tahun 2007, calon gubernur Cornelis kala itu dilihat sebagai orang Dayak, yang melawan Usman Dja'far, Akil Mochtar, dan Osman Sapta sebagai orang Melayu. Begitu juga pada pemilihan gubernur tahun 2012, calon gubernur petahana (Cornelis) dilihat sebagai Dayak, dan lawannya adalah Morkes Effendi, Armyn Ali Anyang, dan Tambul Husin dilihat sebagai orang Melayu. Situasi yang seperti ini terlihat pula dalam pemilihan bupati dan pejabat atau pemegang jabatan strategis lainnya di struktur daerah.

Ada semacam persaingan atau perlombaan dalam membentuk dan mengukuhkan identitas budaya. Pada sisi tertentu, hal ini berdampak positif bagi pewarisan nilai-nilai yang dipilih dan dipelihara sebagai identitas. Orang Dayak menerima warisan upacara adat, seni tari, seni musik, seni ukir, bahasa daerah, kuliner, dan lain-lain yang dikenal di dalam kebudayaannya. Mereka mengembangkannya dalam kegiatan-kegiatan budaya sebagai ciri khas mereka. Begitu juga dengan orang Melayu. Sama seperti orang Dayak, mereka pun mewariskan aneka kerajinan tangan, aneka kuliner dan upacara adat tertentu. Lalu, karya-karya dan kegiatan-kegiatan budaya itu menjadi ciri khas mereka.

Budaya yang dikembangkan oleh orang Dayak dan orang Melayu itu memperkukuh ciri masing-masing. Ciri yang membuat mereka terlihat berbeda dibandingkan yang lain. Perbedaan itu semakin besar dan jelas melalui penguatan yang diberikan oleh masingmasing ke-lompok. Kreativitas tumbuh dari ruang-ruang subjektif yang dimiliki oleh setiap anggota kelompok, dengan ideologi dan rasa yang berbeda, meskipun dari akar-akar budaya yang ada yang sebelumnya sama (Yusriadi, 2017: 63-66).

Dari sisi teori identitas, sesungguhnya apa yang terjadi dapat dipahami sebagai bagian dari pilihan pragmatis. Setiap orang sebagai pelaku dan pemangku budaya, baik dari kalangan Dayak maupun dari kalangan Melayu, sedang berupaya memperkuat identitas yang ada. Mereka menggunakan bahan yang ada, yang mereka peroleh dari warisan sebelumnya, kemudian menambah bahan itu dengan kreativitasnya. Imaginasi dari pencipta, bayangan mereka tentang diri dan kelompok lain melahirkan bentukbentuk seperti yang terlihat sekarang ini di tengah budaya Dayak dan Melayu di Kalimantan Barat.

Ada dampak positif dan negatif dari dinamika itu. Dampak positifnya, 
Handep, Vol. 1, No. 2, Juni 2018 : 1-16

persaingan itu menghasilkan karyakarya budaya yang beragam dan indah. Kecintaan pada budaya serta keinginan menggali budaya lama yang bisa dijadikan sebagai bahan pemertahanan identitas pun menjadi semakin kuat. Kalbar yang terlihat hari ini menjadi lebih berwarna dan tampilan budayanya menjadi lebih marak. Di sisi lain, dampak negatif yang muncul adalah terjadinya "perlombaan" dan rivalitas etnik yang semakin menjadi-jadi. Apatah lagi ketika situasi ini dijadikan sebagai bahan bakar dalam persaingan politik untuk membangkitkan emosi dan soliditas para pendukungnya.

Identitas Dayak dan Melayu dilihat sebagai ciri yang membuat dua komunitas itu semakin jelas berbeda. Perbedaan ini berpotensi mengarah kepada konflik. Sekalipun konfliknya belum terlalu terbuka, tetapi panas yang ditimbulkan dari situasi itu sudah terasa. Bahang panas membakar emosi hampir semua orang dan mempertajam dua kelompok tersebut. Kejadian-kejadian kecil dapat dengan mudah menjadi besar, karena kejadian kecil itu sesungguhnya hanya pemicu saja. Pemicu dari ketegangan yang sebenarnya sudah ada sebelumnya. Semakin lama menjadi semakin kuat dan bertambah banyak. Sebuah peristiwa politik yang terjadi di Jakarta, pada akhirnya bisa menjadi urusan sosial di Kalimantan Barat.

Jika yang dipahami dan diterapkan oleh masyarakat adalah pandangan tentang konsep identitas sebagai sesuatu yang cair, maka sesungguhnya tidak perlu ada kekhawatiran yang besar mengenai penguatan identitas berbahan budaya. Suatu saat, dalam perjalanan waktu, identitas itu akan berubah. Para genius (aktor) dari setiap kelompok akan memasukkan kreativitas mereka dalam pengembangan kebudayaan yang dimiliki oleh masing-masing kelompok. Nantinya hasil kreativitas dari para genius itu bisa menjadi alternatif pilihan di dalam pembentukan unsur-unsur baru bagi sebuah identitas. Jika pun para genius itu menginginkan untuk mengembangkan dan memanfaatkan perbedaan identitas secara positif, maka arah kreativitas bisa didorong ke arah membangun kebersamaan dalam bidang budaya antara Dayak dan Melayu.

Mungkin benar bahwa di sinilah peran kesadaran bersama untuk hidup berdampingan dengan aman dan damai dapat dijadikan pilihan. Kearifan masing-masing pihak akan membuat dampak positif dari adanya perbedaan itu semakin bertahan dan berkembang. Sebaliknya, dampak negatifnya ditinggalkan, dilupakan, dan semakin lama semakin menghilang.

Pilihan lainnya adalah membangun kesadaran kolektif untuk mencari identitas bersama di antara perbedaan yang ada. Identitas yang bisa saling menjauhkan dan tidak disukai secara psikologis oleh orang ataupun kelompok lain bisa ditinggalkan. Sebaliknya, identitas yang dipilih dan digunakan hanya identitas tertentu saja. Bagaimanapun, sesuatu yang tidak lagi diterima secara kolektif akan 
ditinggalkan dan lambat laun akan hilang karena tidak digunakan.

Terakhir, penulis ingin memaparkan sebuah fakta menarik yang perlu untuk dicermati bersama-sama dalam konteks identitas etnik ini. Pada kegiatan Festival Seni Budaya Melayu (FSBM) yang diselenggarakan oleh MABM Kalimantan Barat di Singkawang tahun 2016 lalu, panitia menyediakan baju Melayu khusus untuk panitia dan pengurus. Baju Melayu yang dikenal dengan istilah baju telok belanga itu berwarna merah. Pilihan baju berwarna merah mengundang pertanyaan beberapa orang karena selama ini Melayu identik dengan warna kuning yang menjadi warna kebesarannya. Sedangkan di Kali-mantan Barat, warna merah sering dianggap sebagai warna yang menjadi ciri khas Dayak, meskipun warna merah sering pula digunakan oleh orang Madura dan Cina.

Pilihan panitia menggunakan warna ini sesungguhnya mencerminkan sisi cair sebuah identitas. Warna merah sebagai simbol yang sempat melekat atau beku menurut konsep identitas- pada masyarakat dan budaya tertentu ternyata telah mengalami pencairan. Pencairan ini berdampak positif bagi komunitas lain karena akan menunjukkan adanya persamaan dari sisi bahan warna. Mungkin saja suatu saat nanti persamaan itu akan terlihat dari sisi pola atau atribut tertentu yang bisa dipilih untuk mendekatkan dua kelompok ini.
Jika yang terjadi di FSBM itu bisa dilanjutkan, baik oleh MABM sendiri maupun oleh DAD, maka kekhawatiran akan munculnya konflik antarkelompok karena perbedaan identitas yang menyebabkan perbedaan jarak yang semakin jauh antarkelompok tersebut bisa menjadi berkurang. Konflik yang diramalkan mungkin terjadi dalam siklus tertentu karena situasinya sama atau akumulatif (Alqadrie, 2012: 203) bisa dihindari. Kini terpulanglah pada para elite atau para genius yang menjadi agen perubahan dalam masing-masing kelompok. Pilihan ada pada mereka untuk mendorong dan menciptakan perubahan ke arah yang positif.

\section{PENUTUP}

Dayak dan Melayu merupakan dua kelompok besar yang ada di Kalimantan Barat. Pada mulanya, perbedaan identitas itu ditandai dengan perbedaan agama, dengan paksinya adalah agama Islam. Orang Islam, khususnya pribumi, di Kalimantan Barat dikategorikan sebagai Melayu, sedangkan orang pribumi bukan Islam disebut Dayak. Identitas Melayu telah dipakai lebih awal dan diterima secara meluas sejak awal. Sedangkan identitas Dayak dipakai dan diterima kemudian.

Kedua kelompok itu hidup dalam ruang geografi dan sosial yang sama. Mereka terlibat interaksi antarsatu dengan yang lain di hampir semua bidang kehidupan. Urusan-urusan administrasi, ekonomi, pendidikan, dan sebagainya, hampir tidak mungkin terjadi tanpa adanya relasi lintas etnik. 
Handep, Vol. 1, No. 2, Juni 2018 : 1-16

Namun dalam situasi tertentu pasang surut hubungan mereka diwarnai dengan persaingan, ketegangan, dan konflik.

Di tengah situasi itu identitas masing-masing diperkuat dan dipertahankan. Salah satu bahan dasar pembentuk dan penguat identitas adalah budaya. Bahan budaya itu dikembangkan menjadi penanda simbolis yang membedakan antara yang satu dengan yang lain. Proses penguatan dan pemertahanan identitas ini justru membuat kedua kelompok terlihat semakin dipisahkan oleh pembatas yang tebal dan jelas.

Hatta, identitas Dayak dan Melayu memang tetap cair dan terus menerus mengalami perubahan. Namun gerakan perubahan identitas itu cenderung membawa kedua kelompok ke arah yang berlawanan, sehingga semakin memperlebar jarak antara keduanya. Sebaliknya, sifat cair identitas yang bisa terus menerus berubah dalam konteks yang saling mendekatkan hubungan antara kelompok Dayak dan Melayu baru dilakukan dalam konteks yang terbatas dan belum menimbulkan kesan yang signifikan.

Tentu saja situasi seperti ini menimbulkan kekhawatiran bayak pihak. Oleh karena itu agar rivalitas bergerak ke arah yang lebih positif, pembentukan identitas dari bahan budaya harus dilakukan dalam konteks mendekatkan dua kelompok utama tersebut. Konsep budaya sebagai perekat bangsa atau konsep kehidupan multikultur harus diwujudkan secara nyata dan teraktualisasi dalam kehidupan masyarakat yang majemuk.

\section{DAFTAR SUMBER}

Abdurrahman. 2009. Identiti dan Pembentukan Identiti. Jurnal Akademika 55, hlm. i-xii.

A.B., Shamsul. 1996. Debating about Identity in Malaysia: A Discourse Analysis. Southeast Asian Studies Vol 3, hlm. 476-499. 2001. Identiti dan Etnisiti: Tinjauan Teoritis, dalam Yusriadi dan Haitami Salim (ed.). Prosiding Kolokium Dayak Islam di Kalimantan Barat. Pontianak: STAIN Pontianak-FUI-MABM, hlm.11-30.

Aju dan Syafaruddin Usman. 2012. J.C. Oevaang Oeray, Langkah dan Perjuangannya. Pontianak: CV Samudera Mas.

Aju dan Zainuddin Isman. 2013. Kalimantan Barat, Lintasan Sejarah dan Pembangunan. Pontianak: LPS Air.

Alloy, Sujarni, et al. 2009. Mozaik Dayak di Kalimantan Barat. Pontianak: Institut Dayakologi

Alqadrie, Syarif Ibrahim. 2012. Matahari Terbit dari Barat. Pontianak: Borneo Tribune Press. 
Collins, James T. 1999. Keragaman Bahasa di Kalimantan Barat. Makalah pada Festival Budaya Nusantara Regio Kalimantan, Pontianak. September.

Colongon Jr., Arellano A. 2013. "Dahaga untuk Mengetahui Lebih Banyak tentang Masyarakat Adat Dayak Kalimantan Barat”. Dalam Wahono, FX. et al., Gerakan Pemberdayaan Pancur Kasih. Pontianak: ID.

Djajadi, Iqbal. 2016. Kekerasan Etnik dan Perdamaian: Menelaah Penyelesaian Tindak Pindana Lintas Etnik dalam 4 Tahun Terakhir di Kalimantan Barat, diunduh dari Iqbal-djajadi. blogspot.com, pada 28 Agustus 2017.

Enthoven, J.J.K. 1903. Bijdragen tot de Geographie van Borneo's Westerafdeeling. Leiden: E.J. Brill.

https://kbbi.kemdikbud.go.id, diakses pada Agustus 2017.

Hulten, Herman Josef van. 1987. Catatan Seorang Missionaris di Tengah Suku Dayak. Bandung: Grassindo.

Mahathir bin Mohamad. 1997. Dilema Melayu. Terjemahan. Kuala Lumpur: Times Books International.
Mesthrie, R dan Tabouret-Keller. 2001. "Identity and Language," dalam R. Mesthrie, Concise Encyclopedia of Sociolinguisticts. Amsterdam: Elsevier, hlm. 165-168.

Pasti, Alkap. 2003. "Dayak Islam di Kalimantan Barat, Masa Lalu dan Identitas Kini," dalam Budi Susanto (ed.), Identitas dan Poskolonialisme di Indonesia. Yogyakarta: Penerbit Kanisius.

Purba, Juniar, et al. 2011. Penyebaran dan Pengaruh Budaya Melayu di Kalimantan. Jakarta: Direktorat Nilai Sejarah, Kementerian Kebudayaan dan Pariwisata.

Suara Pimred. 2016. Pro Kontra Raperda Masyarakat Hukum Adat. 15 Agustus.

Sumama (ed.). 2013. Islam dan Budaya Lokal. Pontianak: STAIN Pontianak.

Veth, PJ. 1854. Borneo's Westerafdeeling. Geographisch, Statisticsh, Historisch. Zaltbommel: Joh. Noman en Zoon.

Wahono, Francis X., et al. 2013. Gerakan Pemberdayaan Pancur Kasih. Pontianak: ID.

Yusriadi. 2002. Fenomena Masuk Islam di Pedalaman Kalbar: Menyusuri Etimologi Masuk Melayu. Jurnal Khatulistiwa. Vol 2 (2), hlm. 1-12. 
Handep, Vol. 1, No. 2, Juni 2018 : 1-16

2005. Bahasa dan Identiti di

Riam Panjang. Disertasi. Kuala

Lumpur: Institut Alam dan

Tamadun Melayu, Universiti

Kebangsaan Malaysia.

. 2006. Batas Etnik Dayak-

Melayu di Kalbar: Perspektif

Linguistik. Dalam Chong Shin,

Karim Harun dan Yabit Alas, Reflections in Borneo River, Book

I. Pontianak: STAIN Pontianak Press.

2008a. Memahami

Kesukubangsaan di Kalimantan

Barat. Pontianak: STAIN

Pontianak Press.

2008b. Menunggu Patung

Naga Singkawang menjadi

Patung Naga Api, diunduh dari www.yusriadiebong.blogspot.com, pada 26 September 2017.

. 2009. Problem Memilih

Identitas, diunduh dari www. yusriadiebong.blogspot.com, pada 27 Desember 2013.

. 2014. Bahasa dan Identiti

Melayu di Riam Panjang. Bangi: Institut Alam dan Tamadun Melayu dengan kerjasama South Asia Studies Regional Exchange Program (SEASREP). . 2017. Jongkong, Potret Perubahan Masyarakat
Pedalaman di Kalbar. Pontianak:

IAIN Pontianak Press.

Yusriadi dan Hermansyah. 2003. Orang Embau. Potret Masyarakat Pedalaman Kalimantan. Pontianak: STAIN Pontianak Press.

Yusriadi dan Fahmi Ichwan (ed.). 2007. Dayak Islam di Kalimantan Barat. Pontianak: STAIN Pontianak Press.

Yusriadi, Hermansyah, dan Dedy Ari Asfar (ed.). 2007. Etnisitas di Kalimantan Barat. Pontianak: STAIN Pontianak Press.

Yusriadi dan Haitami Salim (ed.). 2001. Dayak Islam Memasuki Gerbang Abad ke-21. Pontianak: STAIN Pontianak. 